\title{
Isolation and Identification of Fungi Associated with Fruits Sold in Local Markets
}

\author{
Zahra Ibrahim El-Gali \\ Department of Plant Protection, Faculty of Agriculture, Omer Al-Mukhtar University, \\ El-Beida, Libya
}

\begin{abstract}
A total of 12 species of fungi representing eight genera were found to be associated with the rotten fruits collected from the markets of El-Beida city. The fungi isolated from the fruits were Alternaria alternata, A. niger, Colletotrichumgloeosporioides, Colletotrichumacutatum, Fusariumoxysporum Geotrichumc and idum, Penicilliumdigitatum., Penicilliumitalicum, and Rhizopusnigricans. Species of G. candidum, B. cinerea, and $R$. nigricans., were found to be associated as the predominantfungus with the rotten fruits. The higher diversity 4 species of fungi was found in guava, and the lowest one species in banana, pear and rock melon fruits.
\end{abstract}

Keywords: Fruits, fungi, rot, postharvest disease

\section{INTRODUCTION}

Fruits are attacked by fungi, bacteria and other agents causing different types of disease. Over 25 to 30 per cent loss of fruits are caused by fungal diseases in transit and storage. Fruits may be affected either by dry or soft rot. Soft or pulpy fruits undergo a soft or wet rot because of the abundance of water in their tissue (Defosent 1933). The common postharvest and storage fungi of fruits are Alternariaalternata, Aspergillusspp.,Fusariumspp.,Geotrichumsp. Rhizopusnigricans, R. stolonifer, Penicilliumspp. And Sclerotiniasclerotorum (Singh and Sharma 2007 ; Bhale 2011; El-Gali, 2008 ; 2010 ; 2014 ; Ammar and El-Naggar 2015). Therefore, the present investigation was undertaken to find out the association of fungi with the rotten fruits in local markets of El-Beida city and to identify them.

\section{Materials AND Methods}

\subsection{Fruit Source and Isolation, Identification of Fungi}

A survey of crop fungi were conducted on nine economically important fruits i.e. Apple, Banana, Grape, Guava, Orang, Peach, Pear Rock melon and Strawberry during 2015, 2016 seasons. Naturally infected fruits of were purchased from local markets in El-Beida city, Libya. Samples were brought to the Microbiology laboratory at Agriculture College University, Omer, Al-Mukhtar, in separate sterilized polythene bags, examined critically with respect to symptomatology and sorted out for the isolation of the causal agents.

The fruits washed with water, their surface were sterilized by exposing them in $1 \%$ sodium hypochlorite and then rinsed three times in sterile distilled water. Segments $(3-5 \mathrm{~mm})$ of tissues from the margins of the rotted areas were cut out with a sterile scalpel and placed on previously prepared potato dextrose agar (PDA) amended with tetracycline at $12 \mu \mathrm{g} / \mathrm{ml}$, in Petri dishes and incubated at 25 $\pm 1^{\circ} \mathrm{C}$ for 5 days under $12 \mathrm{~h}$ photoperiod. The fungus was purified. The pathogen that appeared was primarily identified up to species level using cultural and morphological features under the light microscopic (CMI 1966 ; Pitt, 1991; Barnett and Hunter ; 1999) and maintained on PDA slants for further studies. In some cases, rotting fruit samples were incubated in a moist chamber and mycelium of individual fungal species transferred onto PDA plates and incubated for 3-7 days at a temperature of $25^{\circ} \mathrm{C}$. Percent frequency of the occurrence of the fungal isolates was calculated. The symptoms of different rotten fruits were recorded and presented in Fig.1.

\section{RESUltS AND DisCUSSION}

\subsection{Symptoms on Fruits}

Different symptoms are restricted to the fruits peel surface tabulated in Figure 1.These symptoms include brown to dark area (Fig. 2.A), water-soaked area with dusting of grey spores (Fig. 1,B) on 
strawberry respectively. White rot on rock Mellon (Fig. 1.C), orange covered with masses of blue pale spores (Fig. 1.D), darkening sunken lesions on banana (Fig. 1.E), Bull's eye rot on yellow apple (Fig. 1.F), black spot with concentric zones embedded in the disease tissues of stored pear (Fig. 1.G), Rough tissues with shrinking surface skin on grape (Fig. 1.H). Rough tissues and water-soaked area Such area gradually increases in size and turn brown with translucent margins and covered with concentric zones embedded in the disease tissues on peach fruits (Fig. I,J).soft watery increases in size with fungal growth (Fig. 1. K), rotten fruits were, brown, watery, smooth or with shrinking surface skin apple (Fig. 1.L), soft watery and green spores are produced on citrus fruits (Fig. 1.M) and brown area that cover more than $50 \%$ of the fruit surface (Fig. 1.N), brown lesion on calyx as brownish water-soaked area with fungal growth (Fig. 1.O) on apple.

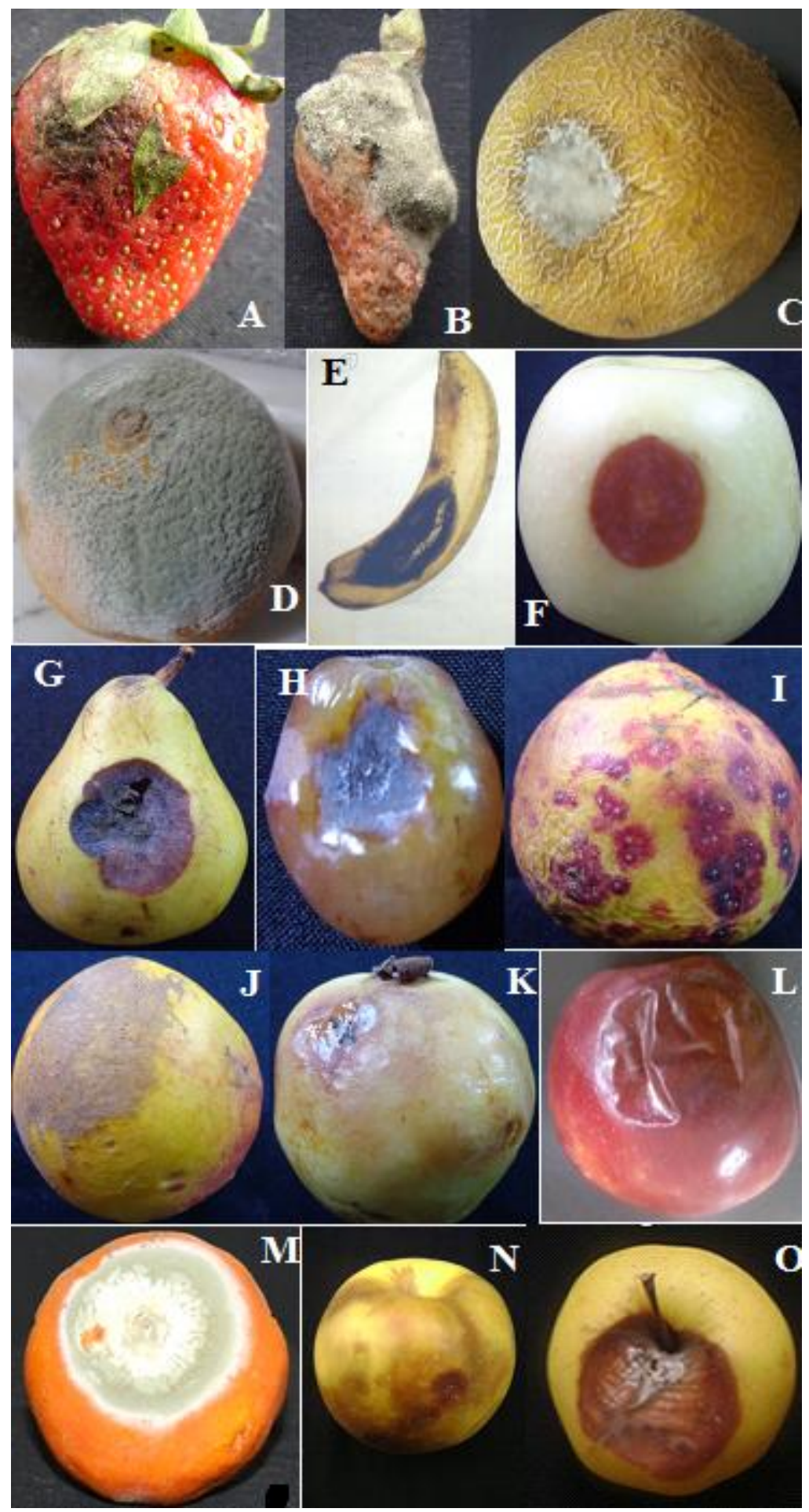

Figure1. Symptoms rotten of different fruits $A$ - $O$ represent rot of strawberry $(A, B)$, rock melon $(C)$, Orange $(D)$, banana $(E)$, yellow apple $(F)$, pear $(G)$, grape $(H)$, peach $(I, J)$, guava $(K)$, red apple $(L)$, Orange $(M)$, yellow apple $(N, O)$. 
Isolation and Identification of Fungi Associated with Fruits Sold in Local Markets

Table2. Percent frequency of association of fungi with rotten fruits

\begin{tabular}{|l|c|c|c|c|c|c|c|c|c|c|c|}
\hline \multirow{2}{*}{ Name of fungi } & \multicolumn{7}{|c|}{ Percentage of fungi on fruits } & \multirow{2}{*}{ T. } & M. \\
\cline { 2 - 13 } & Apple & Banana & Grape & Guava & Orange & Peach & Pear & $\begin{array}{c}\text { Rock } \\
\text { melon }\end{array}$ & Strawberry & & \\
\hline A niger & - & - & 41.6 & - & - & - & - & - & - & 41.6 & 4.62 \\
\hline A alternata & & - & - & 8.3 & - & - & 41.6 & - & - & 49.9 & 5.54 \\
\hline B cinerea & 44.0 & - & - & - & - & - & - & - & 16.7 & 60.7 & 6.74 \\
\hline C. acutatum & & 25.0 & - & - & - & - & - & - & & 25.0 & 2.8 \\
\hline C. gloeosporioides & & - & - & - & - & - & - & - & 25.0 & 25.0 & 2.8 \\
\hline Fusariumsp. & & - & - & 8.3 & - & - & - & - & - & 8.3 & 0.92 \\
\hline G. candidum & & - & - & 16.7 & - & 25.0 & - & 41.6 & - & 83.3 & 9,25 \\
\hline Neofabraeasp. & 41.6 & - & - & - & - & - & - & - & - & 41.6 & 4.62 \\
\hline P. digitatum & - & - & - & - & 44.0 & - & - & - & - & 44.0 & 4.90 \\
\hline P. expansum & 41.6 & - & - & - & - & - & - & - & - & 41.6 & 4.62 \\
\hline P. italicum & - & - & - & - & 25.0 & - & - & - & - & 25.0 & 2.8 \\
\hline R. nigricans & - & - & - & 25.0 & - & 25.0 & - & - & - & 50.0 & 5.6 \\
\hline Total & 127.2 & 25.0 & 41.6 & 58.3 & 69 & 50 & 41.6 & 41.6 & 41.7 & & \\
\hline Mean & 10.6 & 2.1 & 3.5 & 4.9 & 5.8 & 4.2 & 3.5 & 3.5 & 3.5 & & \\
\hline
\end{tabular}

T: Total, M: Mean

The mycological analysis of nine fruit crops samples revealed that, 12 fungal species belonging to nine genera were associated with fruit symptoms. Data in Table (2) indicated that, the maximum frequency of fungi in fruits was noticed in apple was the more infected by fungi (127.2\%), following with $69 \%$ in orange, while banana was the less infected of fungi $(25 \%)$. The higher diversity 4 species of fungi was found in guava, and the lowest one species in banana, pear and rock melon. $G$. candidum, (9.25\%), B. cnerea (6.74\%) following $R$ nigricans $(5.6 \%)$ and Alternariaalternata (5.5\%) were the common fungi found as the predominant fungus with the rotten fruits. One of the pathogenic fungi that are associated with fruit rot of grape is Aspergillusniger, C. acutatum with anthracnose symptoms on banana, while, Fusariumsp. was found to be associated rotten symptoms of guava fruits. These results are in agreement with those obtained by Bashar et al. (2012). who found that Fusarium spp. in guava rotten fruits. Also Neofabraeasp. and Pencilliumspp. were isolated only from apple and orange respectively. Several studies reported that the fungi i.e. A. niger (Singh, et al. 2011), A. alternata (Ammar and El-Naggar, 2014), Colletotrichum spp., (Bosquez-Molina et al, 2010 ; Bashar et al., 2012), Pencilliumdigitatum (El-Gali, 2014), Fusarium spp. (Sever et al., 2012) and Geotrichumcandidum (Yaghmour et al. 2012 ; Hafeezetal., 2015).

\section{Conclusion}

Analysis of rotten fruit indicated high fungi contamination. This may be the result of the fruits handling such as washing, sorting and exposure to environmental contaminants. Also the results of this experiment suggests that rotten fruits nourishes various types of fungi. Some of them produces mycotoxin which may cause harm to the consumers. Thus, all the fruits need more hygienic processing to be suitable for human consumption.

\section{REFERENCES}

Ammar, MI., and El-Naggar, MA. (2014). Screening and Characterization of Fungi and their associated Mycotoxins in some Fruit Crops. International Journal of Advanced Research. 2(4): 1216-1227

Bashar, MA., Shamsi, S. and Hossain, M. (2012). Fungi associated with rotten fruits in dhaka metropolis. Bangladesh J. Bot. 41(1): 115-117.

Barnett, H.L. and Hunter, B.B. (1999): Illustrated Genera of Imperfect Fungi (fourth ed.), APS Press, St. Paul, Minnesota, USA.218 pp.

Bhale, C. (2011). Survey of market storage diseases of some important fruits of Osmannabad district, India. Science Research Reporter. 1(2):88-91.

Bosquez-Molina E., Ronquillo-de Jes̊s E., Bautista-Bãnos S., Verde-Calvo JR. and Morales-Lিpez J. (2010). Inhibitory effect of essential oils against Colletotrichumgloeosporioides andRhizopusstolonifer in stored papaya fruit and their possible application in coatings. Postharvest Biology and Technology 57: 132-137 
CMI. "Commonwealth Mycological Institute" (1966). Description of pathogenic fungi and bacteria. Kew, Surry, England.

Defosent, F. (1933). Manual of Fruit Disease. 2nd Ed. McGraw Hill Co. ,New York

El-Gali ZI (2008). Control of decay of apple fruits used by Calcium and Sodium chloride salts. AlMukhtar J. of Sci., 20:97- 111.

El-Gali, Z.I. (2010). Cultural, Morphological and Physiological studies on some isolates of Sclerotiniasclerotiorum. Libyan J. of Pl. Prot.1: 11-16. (In Arabic).

El-Gali ZI (2014). Control of Pencilliumdigitatum on orang fruits with calcium chloride dipping. J. Microbiol. Rec. and Rev., 2(6): 54- 61.

Hafeez, R., Akhtar, N., Shoaib, A., Bashir, U., Haider, MS. and Awan ZA. (2015). First report of Geotrichumcandidum from postharvest sour rot in Loquat. J. Animal \& Pl. Sci., 25(6): $1737-$ 1740 .

Larous L., Hendel N., Abood JK and Ghoul M (2007). The growth and production of patulinmycotoxin by Penicilliumexpansumon apple fruits and its control by the use of propionic acid and sodium benzoait. Arab J. of Plant Protect.,25(1): 123-128.

Madani B., Mohamed MT., Biggs AR., Kadir J., Awang Y., Tayebimeigooni A. and Shojaei TR (2014) Effect of pre-harvest calcium chloride applications on fruit calcium level and post-harvest anthracnose disease of papaya. Crop Protect., 55: 55- 60.

Pitt JI (1991). Laboratory guide to common PenicilliumSpecies. Commonwealth Scientific and Industrial Research Organization. Food Research laboratory, N.S.W. Australia.

Sever Z., Ivić D., Kos T. and Miličević T. (2012). Identification of Fusariumspeciesisolated from stored apple fruit in Croatia. ArhHigRadaToksikol. 63:463-470

Singh, D. and Sharma, R.R. (2007). Postharvest diseases of fruit and vegetables and their management. In: Prasad, D. (Ed.), Sustainable Pest Management. Daya Publishing House, New Delhi, India

Singh H., Fairs G. and Syarhabil M. (2011). Anti-fungal activity of Capsicum frutescence and Zingiberofficinaleagainst key post-harvest pathogens in citrus. International Conference on Biomedical Engineering and Technology 1- 6.

Yaghmour, M. A., R. M. Bostock, D. P. Morgan and T. J. Michailides (2012). Biology and sources of inoculum of Geotrichumcandidumcausing sour rot of peach and nectarine fruit in California. Plant Dis., 96: 204-210. 